\title{
Variations of trace gases over the Bay of Bengal during the summer monsoon
}

\author{
I A Girach ${ }^{1, *}$, Narendra Ojha ${ }^{2}$, Prabha R Nair $^{1}$, Yogesh K Tiwari ${ }^{3}$ \\ and K Ravi KumaR ${ }^{4,5}$ \\ ${ }^{1}$ Space Physics Laboratory, Vikram Sarabhai Space Centre, Thiruvananthapuram 695 022, India. \\ ${ }^{2}$ Department of Atmospheric Chemistry, Max Planck Institute for Chemistry, 55128 Mainz, Germany. \\ ${ }^{3}$ Indian Institute of Tropical Meteorology, Pune 411 008, India. \\ ${ }^{4}$ National Institute of Polar Research, Tachikawa, Japan. \\ ${ }^{5}$ Department of Environmental Geochemical Cycle Research, JAMSTEC, Yokohama, Japan. \\ ${ }^{*}$ Corresponding author. e-mail: imran.girach@gmail.com
}

MS received 15 February 2017; revised 5 July 2017; accepted 13 July 2017; published online 16 February 2018

In situ measurements of near-surface ozone $\left(\mathrm{O}_{3}\right)$, carbon monoxide $(\mathrm{CO})$, and methane $\left(\mathrm{CH}_{4}\right)$ were carried out over the Bay of Bengal (BoB) as a part of the Continental Tropical Convergence Zone (CTCZ) campaign during the summer monsoon season of 2009. $\mathrm{O}_{3}, \mathrm{CO}$ and $\mathrm{CH}_{4}$ mixing ratios varied in the ranges of 8-54 ppbv, 50-200 ppbv and 1.57-2.15 ppmv, respectively during 16 July-17 August 2009. The spatial distribution of mean tropospheric $\mathrm{O}_{3}$ from satellite retrievals is found to be similar to that in surface $\mathrm{O}_{3}$ observations, with higher levels over coastal and northern $\mathrm{BoB}$ as compared to central BoB. The comparison of in situ measurements with the Monitoring Atmospheric Composition \& Climate (MACC) global reanalysis shows that MACC simulations reproduce the observations with small mean biases of $1.6 \mathrm{ppbv},-2.6 \mathrm{ppbv}$ and $0.07 \mathrm{ppmv}$ for $\mathrm{O}_{3}, \mathrm{CO}$ and $\mathrm{CH}_{4}$, respectively. The analysis of diurnal variation of $\mathrm{O}_{3}$ based on observations and the simulations from Weather Research and Forecasting coupled with Chemistry (WRF-Chem) at a stationary point over the BoB did not show a net photochemical build up during daytime. Satellite retrievals show limitations in capturing $\mathrm{CH}_{4}$ variations as measured by in situ sample analysis highlighting the need of more shipborne in situ measurements of trace gases over this region during monsoon.

Keywords. Ozone; carbon monoxide; methane; monsoon; Bay of Bengal; MACC reanalysis.

\section{Introduction}

Tropospheric ozone $\left(\mathrm{O}_{3}\right)$ and Methane $\left(\mathrm{CH}_{4}\right)$ are important greenhouse gases with radiative forcing of $0.40 \pm 0.20$ and $0.48 \pm 0.05 \mathrm{Wm}^{-2}$ (IPCC 2013), respectively. Carbon monoxide $(\mathrm{CO})$ is indirect greenhouse gas with an indirect radiative forcing of 0.23 (0.18 to 0.29$) \mathrm{Wm}^{-2}$, through the production of $\mathrm{O}_{3}, \mathrm{CH}_{4}$ and carbon dioxide (IPCC 2013).
As the major source of Hydroxyl radical $(\mathrm{OH}), \mathrm{O}_{3}$ controls the self-cleaning capacity of the atmosphere. Majority of tropospheric $\mathrm{O}_{3}$ is produced by in situ photochemical reactions involving precursor gases $\mathrm{CH}_{4}$, non- $\mathrm{CH}_{4}$ hydrocarbons (NMHCs), and $\mathrm{CO}$ and in presence of nitrogen oxides (Seinfeld and Pandis 2006). The anthropogenic activities such as fossil fuel and biomass burning supplemented with oxidation of hydrocarbons (like $\mathrm{CH}_{4}$ and Isoprene) 
are the major sources of $\mathrm{CO} . \mathrm{CH}_{4}$ is emitted from a variety of natural and anthropogenic sources. About $90 \%$ of $\mathrm{CH}_{4}$ is removed through its reaction with $\mathrm{OH}$.

Tropospheric $\mathrm{O}_{3}$ and its precursors exhibit significant spatial and temporal variability. Elevated $\mathrm{O}_{3}$ levels have been observed at several rural sites and marine environments which are devoid of major local anthropogenic emissions (e.g., Lawrence and Lelieveld 2010 and references therein), primarily due to transport from source regions. The marine environment of the Bay of Bengal (BoB), being geographically surrounded by landmass on three sides, is conducive for advection and accumulation of aerosols and trace gases. The systematic variations in synoptic winds over the BoB make it a unique environment to study the effects of transport on spatial and temporal variability of trace species. The BoB acts as a corridor for the strongest monsoonal systems of the world (the Indian summer monsoon) and lying downwind to most populated regions of the globe such as South and Southeast Asia.

Several field campaigns such as Indian Ocean Experiment (INDOEX), Integrated Campaign for Aerosols, gases and Radiation Budget (ICARB), winter-ICARB (W-ICARB), Bay of Bengal Experiment (BOBEX)-I, BOBEX-II, Bay of Bengal Process Studies (BOBPS), and a campaign during October-November 2010 have been conducted to measure the variations in trace gases over the BoB. Earlier studies (Lal et al. 2006, 2007; Sahu et al. 2006; David et al. 2011; Nair et al. 2011; Srivastava et al. 2012; Mallik et al. 2013; Girach and Nair 2014) have covered the spatio-temporal distribution in trace gases during most of the seasons over the BoB, however such measurements have been non-existing during the summer monsoon season (June-August). Various experiments (Lal et al. 1998; Chand et al. 2001, 2003; Lal and Lawrence 2001; Naja et al. 2004; Ali et al. 2009) discuss spatio-temporal variabilities in trace gases over the Arabian Sea (AS) and the Indian Ocean (IO). The earlier studies have analysed the diurnal variation of surface $\mathrm{O}_{3}$ over the marine regions. Monsoonal circulation, stronger convection and cloudy/rainy conditions prevailing during the summer monsoon are anticipated to result in chemical and dynamical effects on atmospheric composition of this region. Therefore, to fill the gap of observations, in this paper we analyze ship-based measurements of surface $\mathrm{O}_{3}$ along with $\mathrm{CO}$ and $\mathrm{CH}_{4}$ over the $\mathrm{BoB}$ during summer monsoon conducted as a part of the
Continental Tropical Convergence Zone (CTCZ) experiment under Indian Climate Research Programme (ICRP) of Government of India during July-August 2009. We have studied the diurnal variation of surface $\mathrm{O}_{3}$ at a stationary point over the BoB during monsoon season.

We have reported the measured spatial and temporal variations in trace gases over the BoB recently (Girach et al. 2017), which we here further extend by further analysis and comparison with global reanalysis from Monitoring Atmospheric Composition \& Climate (MACC). We have also compared the observed mixing ratios and their variabilities with those observed over the $\mathrm{BoB}$, the AS and the IO. The manuscript begins with a description of cruise track in section 2, followed by the experimental details and data in section 3 . Model simulations are described in section 4 and results of the work are presented in section 5. A summary of the results is provided in section 6 .

\section{The cruise track}

The cruise track of the Oceanic Research Vessel Sagar Kanya during the CTCZ experiment (cruise number-SK 261) is shown in figure 1 . The dates corresponding to the mean position of the ship are marked along the cruise track in the figure. The arrows marked on the track show the direction of the movement of the ship. The ship sailed over the $\mathrm{BoB}$ starting and ending at Chennai $\left(80.3^{\circ} \mathrm{E}\right.$, $13.1^{\circ} \mathrm{N}$ ) during 16 July-17 August 2009, having longitudinal and latitudinal scans. The ship was kept stationary during July 22 to August 6, 2009 (15 days) at $89^{\circ} \mathrm{E}, 19^{\circ} \mathrm{N}$ as marked by a square in the figure for time series measurements. The wind pattern at $925 \mathrm{hPa}$ (not shown here) during the cruise period was westerly/southwesterly, which was conducive for the transport of $\mathrm{O}_{3}$ and its precursors from the Indian landmass to the BoB during the summer monsoon season. Further details are given in Girach et al. (2017).

\section{Experimental details and data}

The measurements of surface $\mathrm{O}_{3}$ and $\mathrm{CO}$ were conducted using an online UV photometric ozone analyser (Model O3 42) and online gas filter correlation CO analyser (Model CO12 Module) respectively, from Environnement S.A, France. The $\mathrm{O}_{3}$ analyser operates on the principle of absorption of ultraviolet (UV) radiation at $253.7 \mathrm{~nm}$ using the 


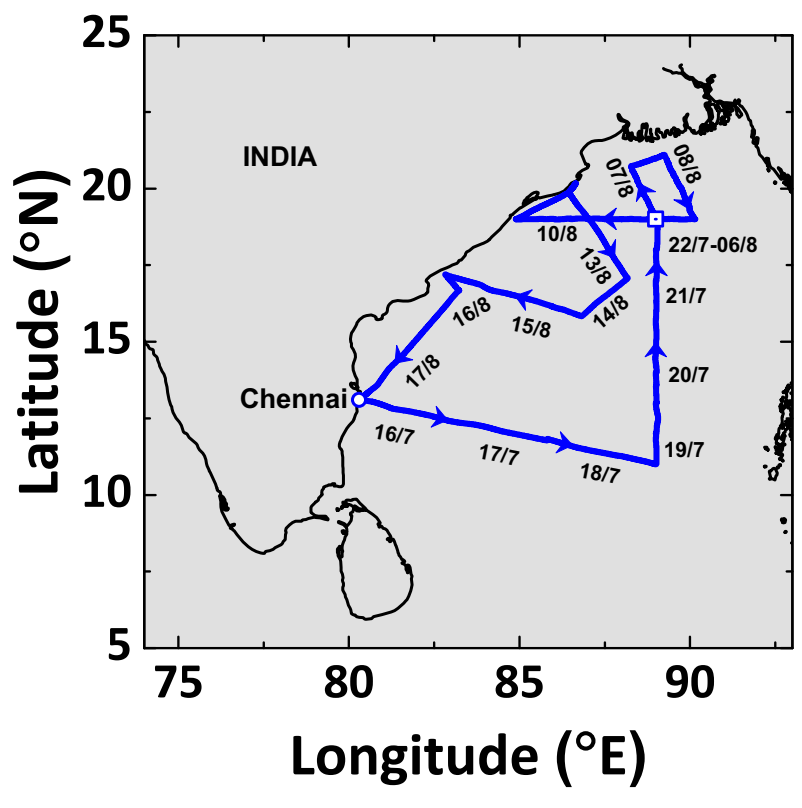

Figure 1. Cruise track (continuous blue line) of the Research Vessel Sagar Kanya during the CTCZ experiment (16 July17 August 2009). Arrows marked on the track show the ship direction. The dates corresponding to approximate ship positions are marked along the track. The circle shows the start and end point of the cruise. The location at which the ship was kept stationary (July 22-August 6, 2009) is marked with a square.

Beer-Lambert law. This instrument has an uncertainty of $5 \%$ and lower detection limit of 1 ppbv. The CO-analyser works on the principle of Non Dispersive Infrared (NDIR) absorption of $\mathrm{CO}$ at $4.67 \mu \mathrm{m}$. CO-analyser has an uncertainty of $10 \%$ and lower detection limit of 50 ppbv. More technical details and methodology are given elsewhere (Girach et al. 2017).

Air was drawn from a height of approximately $15 \mathrm{~m}$ above the sea surface through a teflon tube. Before and after the cruise, both the analyzers were calibrated using custom-made calibrator. The measurements affected by ship exhaust were filtered prior the analysis. Additionally, the air samples, a total of 29 collected in the glass flasks (1 litre) during the ship cruise, were analyzed for methane using a gas chromatograph (GC). A detailed description of the analytical procedure for sampling and analysis is given in Ravikumar et al. (2014). The precision for methane measurements is approximately $\pm 0.1 \mathrm{ppmv}$.

The Ozone Monitoring Instrument (OMI) and the Microwave Limb Sounder (MLS) on board the EOS Aura spacecraft provide total columnar $\mathrm{O}_{3}$ and stratospheric $\mathrm{O}_{3}$ measurements. Combining these two retrievals, tropospheric column $\mathrm{O}_{3}$ is determined by subtracting measurements of MLS stratospheric column ozone from OMI total column ozone after adjusting for the intercalibration differences of the two instruments using the convective cloud differential method (Ziemke et al. 2006). The monthly mean tropospheric $\mathrm{O}_{3}$ (mean volume mixing ratios in ppbv) is used in the present study to compare its average spatial variation with that of surface $\mathrm{O}_{3}$. The monthly mean tropospheric $\mathrm{O}_{3}$ with a resolution of $1^{\circ}$ latitude $\times 1.25^{\circ}$ longitude is obtained from https://acd-ext.gsfc.nasa. gov/Data_services/cloud_slice/. The mean tropospheric $\mathrm{O}_{3}$ is expressed in volume mixing ratio as $1270 \times \mathrm{TCO} /\left(\mathrm{P}_{\text {surface }}-\mathrm{P}_{\text {Tropopause }}\right)$, where tropospheric $\mathrm{O}_{3}$ mixing ratio is in ppbv, tropospheric column ozone (TCO) is in DU, and $\mathrm{P}_{\text {surface }}$ and $\mathrm{P}_{\text {Tropopause }}$ are in hPa (Ziemke et al. 2006).

Atmospheric InfraRed Sounder (AIRS), a thermal infrared grating spectrometer, on board Aqua spacecraft retrieves $\mathrm{CH}_{4}$ mixing ratios profiles in both clear and partially cloudy conditions based on the measured spectrum around $7.66 \mu \mathrm{m}$. In the latest version 6, 63 channels (out of 200) spanning around $7.66 \mu \mathrm{m}$ are used for the retrievals of $\mathrm{CH}_{4}$. The daily gridded $\left(1^{\circ} \times 1^{\circ}\right)$ level-3 (version 6 ) daytime (ascending orbits) and nighttime (descending orbit) retrievals were used in this study for comparison with the in situ measurements.

\section{Model simulations}

We compare the in situ measurements of $\mathrm{O}_{3}$, $\mathrm{CO}$ and $\mathrm{CH}_{4}$ conducted during this study with a global reanalysis model dataset (MACC at 1000 $\mathrm{hPa}$ ), to evaluate the global model fields in this sparsely measured region. MACC reanalysis data was obtained at a horizontal resolution of $0.25^{\circ} \times 0.25^{\circ}$ and time resolution of $3 \mathrm{hrs}$. MACC model consists of ECMWFs' (European Center for Medium range Weather Forecasting) Integrated Forecast System (IFS) coupled with the MOZART (Model for OZone and Related chemical Tracers)3 chemistry transport model. More details of the MACC reanalysis can be found through its website (https://www.gmes-atmosphere.eu/oper_info/ macc_reanalysis/) or from previous studies (e.g., Inness et al. 2013; Katragkou et al. 2015 and references therein).

WRF-Chem model (version 3.5.1) has been used to simulate the diurnal patterns in $\mathrm{O}_{3}$ over the $\mathrm{BoB}$ to investigate the possible role of in situ 


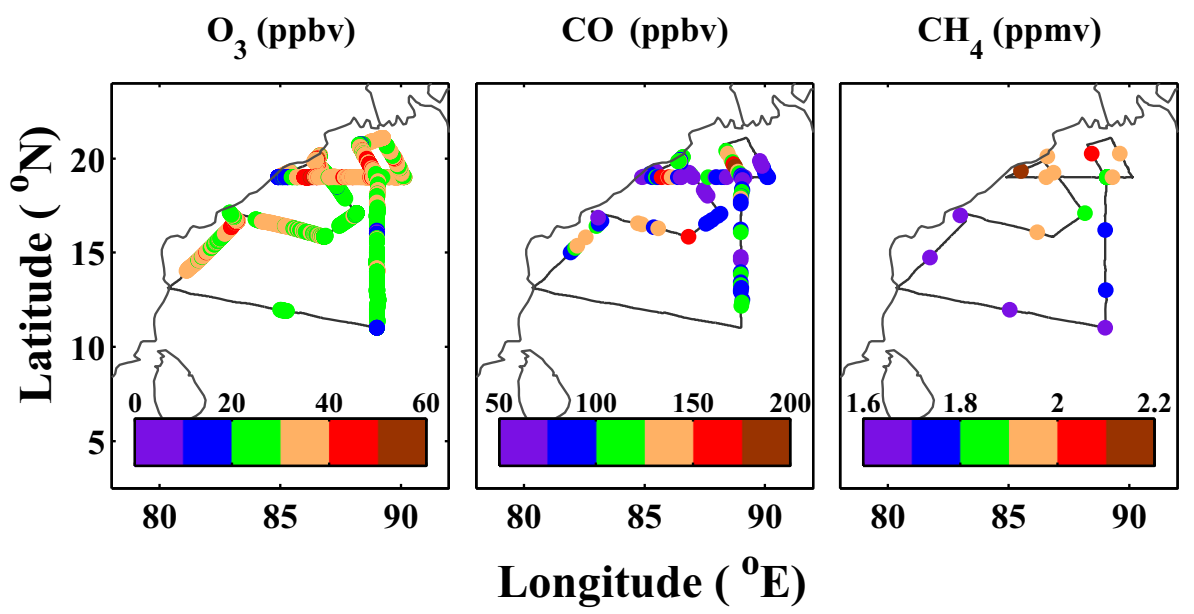

Figure 2. Spatial variation in $\mathrm{O}_{3}, \mathrm{CO}$, and $\mathrm{CH}_{4}$ over the $\mathrm{BoB}$ during 16 July-17 August, 2009 along the cruise track measured during the CTCZ experiment (summer monsoon).

photochemistry over the BoB. The description of WRF-Chem setup and input fields can be found in Girach et al. (2017). Further details of WRF-Chem performance over this region in reproducing variations of trace gases can be found elsewhere (e.g., Ojha et al. 2016; Sharma et al. 2016; Girach et al. 2017 and references therein).

\section{Results and discussions}

\subsection{Variations in trace gases and comparison with $M A C C$ reanalysis}

Figure 2 shows the observed spatial variation in surface $\mathrm{O}_{3}, \mathrm{CO}$ and $\mathrm{CH}_{4}$ along the ship-track during the CTCZ experiment. The spatial and temporal distribution of trace gases discern considerable heterogeneity during the monsoon with $\mathrm{O}_{3}$ mixing ratios varying from as low as 8 ppbv to as high as $54 \mathrm{ppbv}$ with mean value of $29.7 \pm 6.8 \mathrm{ppbv}$. $\mathrm{CO}$ levels were observed to be in the range of 50 ppbv (i.e., lower detection limit) to $200 \mathrm{ppbv}$ with average value of $96 \pm 25$ ppbv. CO mixing ratios below the detection limit were filtered. $\mathrm{CH}_{4}$ mixing ratios showed variation from 1.57 to $2.15 \mathrm{ppmv}$ (average overall observations $=1.83 \pm 0.14 \mathrm{ppmv}$ ) The average mixing ratios of $\mathrm{O}_{3}, \mathrm{CO}$ and $\mathrm{CH}_{4}$ were $\sim 30 \pm 7$ ppbv, $95 \pm 25 \mathrm{ppbv}$ and $1.86 \pm 0.12$ ppmv, respectively, over the north-BoB, which were slightly higher or comparable to those over the central-BoB $\left(\mathrm{O}_{3}: 27 \pm 5\right.$ ppbv, $\mathrm{CO}: 101 \pm 27 \mathrm{ppbv}$ and $\mathrm{CH}_{4}: 1.72 \pm 0.14$ ppmv). For central and north$\mathrm{BoB}$ regions, monsoon time observations indicate higher variability as compared to other seasons.
Figure 3 shows the spatial variation of tropospheric $\mathrm{O}_{3}$ averaged over July-August 2009 over the BoB derived from satellite observations. As seen in figure 2 , surface $\mathrm{O}_{3}$ is slightly higher (3040 ppbv) over north-BoB and along the coast as compared to the central region of the BoB (20-30 ppbv). Similar feature is observed in the case of tropospheric $\mathrm{O}_{3}$. As seen in figure 3, tropospheric $\mathrm{O}_{3}$ is slightly higher (in the range of $35-40 \mathrm{ppbv}$ ) over north-BoB and along the east-coast of India as compared to the central and southern part of the BoB (30-35 ppbv). In short, the broad spatial features of tropospheric $\mathrm{O}_{3}$ compares well with that of surface $\mathrm{O}_{3}$.

We use our measurements over the BoB for the monsoon season to evaluate the performance of a global reanalysis data (MACC) as shown in figure 4. The comparison of MACC reanalysis near the surface (at $1000 \mathrm{hPa}$ ) with in situ measurements shows that MACC reproduces the observed mixing ratios of $\mathrm{O}_{3}, \mathrm{CO}$ and $\mathrm{CH}_{4}$. The estimated mean biases for surface $\mathrm{O}_{3}, \mathrm{CO}$ and $\mathrm{CH}_{4}$ are 1.6 ppbv (5.3\% of average in situ $\mathrm{O}_{3}, 29.7$ ppbv), $-2.6 \mathrm{ppbv}(2.7 \%$ of average in situ $\mathrm{CO}, 96 \mathrm{ppbv})$ and 0.07 (4\% of average in situ $\mathrm{CH}_{4}, 1.83 \mathrm{ppmv}$ ). The small magnitudes of mean biases show the capabilities of MACC reanalysis in reproducing the observed levels. However, it shows a limitation in capturing the variations. The squared correlation coefficients $\left(\mathrm{R}^{2}\right)$ between in situ observations and MACC reanalysis at $1000 \mathrm{hPa}$ are $0.03,0.13$ and 0.25 for $\mathrm{O}_{3}, \mathrm{CO}$ and $\mathrm{CH}_{4}$, respectively. MACC utilizes the assimilation of atmospheric composition from satellite retrievals (Inness et al. 2013). Satellite measurements could have 


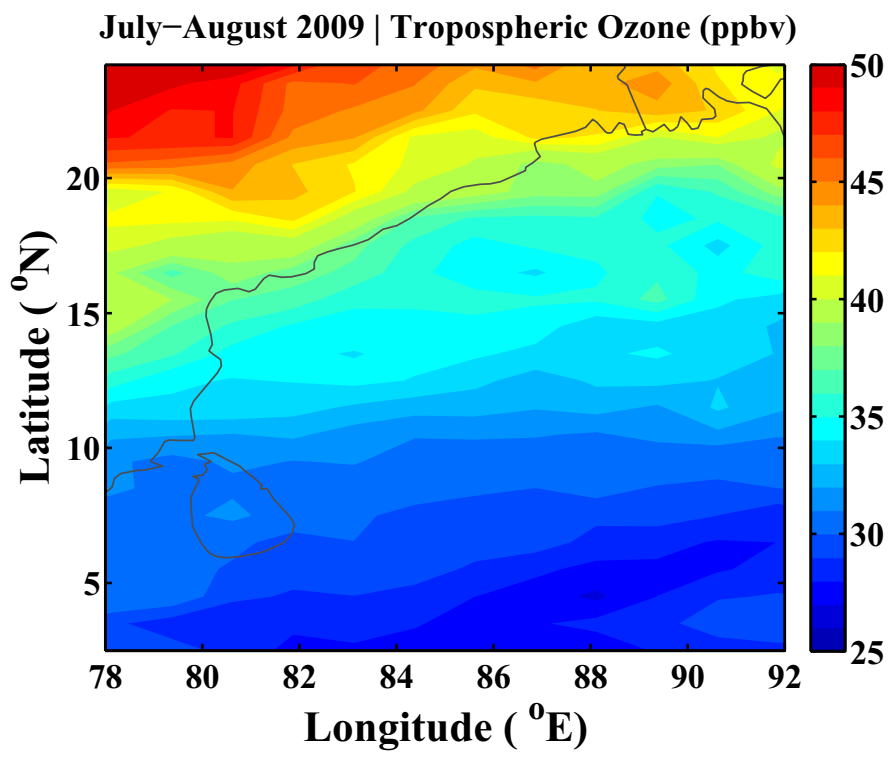

Figure 3. Mean tropospheric $\mathrm{O}_{3}$ (ppbv) averaged over July and August 2009 over the BoB. The data is based on OMI and MLS retrievals and were obtained from their website.

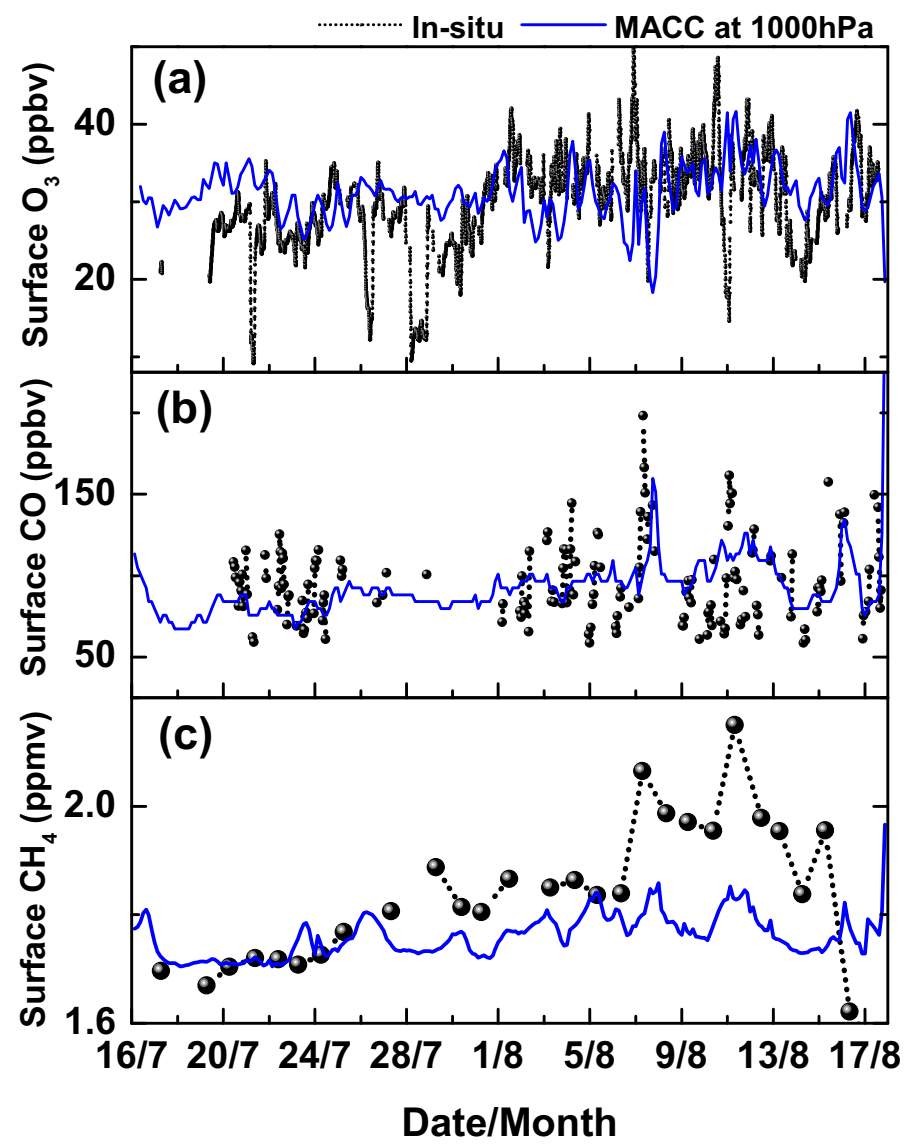

Figure 4. (a, b, c) A comparison of surface $\mathrm{O}_{3}, \mathrm{CO}$ and $\mathrm{CH}_{4}$ from in situ measurements (black dots) with $\mathrm{MACC}$ reanalysis at $1000 \mathrm{hPa}$ (blue line) along the cruise track over the BoB during the CTCZ experiment (summer monsoon season; 16 July-17 August, 2009). The MACC reanalysis data were obtained through its website. 
significant uncertainty during the cloudy rainy conditions, especially, near the surface. This could possibly explain the limitation in capturing the observed variability by MACC reanalysis.

This clearly shows that MACC reanalysis reproduces the observed mean concentration levels of $\mathrm{O}_{3}, \mathrm{CO}$ and $\mathrm{CH}_{4}$ over the $\mathrm{BoB}$ during summer monsoon with a small bias of $2-5 \%$. However, there is a limitation in reproducing observed variabilities of $\mathrm{O}_{3}$ and $\mathrm{CO}$. Variations in $\mathrm{CH}_{4}$ are reproduced better by MACCreanalysis as compared to $\mathrm{O}_{3}$ and $\mathrm{CO}$.

As discussed in Girach et al. (2017), the WRFChem simulations reproduced $\mathrm{O}_{3}$ and $\mathrm{CO}$ mixing ratios with mean biases of 1.9 and $18 \mathrm{ppbv}$ and squared correlation coefficient of 0.58 and 0.19 , respectively. The WRF-Chem simulation reproduced the observation with similar magnitude of biases and better variabilities (higher correlation coefficients).

\subsection{Diurnal variation in $O_{3}$ at a stationary point in the $B o B$}

The ship was kept stationary for a period of 15 days (22 July-6 August 2009 ) at $89^{\circ} \mathrm{E}, 19^{\circ} \mathrm{N}$ and surface $\mathrm{O}_{3}, \mathrm{CO}$ and $\mathrm{CH}_{4}$ varied in the range of 9-6 ppbv, 58-144 ppbv and 1.71-1.89 ppmv, temporally averaged to the $28 \pm 7 \mathrm{ppbv}, 91 \pm 19 \mathrm{ppbv}$ and $1.81 \pm 0.06 \mathrm{ppmv}$, respectively. Figure 5 shows the mean delta-diurnal variation in surface $\mathrm{O}_{3}$, i.e., the mean value subtracted from the mean diurnal pattern from the measurements and WRF-Chem simulations at $89^{\circ} \mathrm{E}, 19^{\circ} \mathrm{N}$ for this period of about 15 days. $\mathrm{O}_{3}$ values at each hour here is an average of 10-15 observations. Ship exhaust contaminated the observations for a period of time between 5 and $14 \mathrm{hrs}$ long; the data corresponding to this period is therefore discarded from the analysis, leading to a gap. Both the WRF-Chem model and observations showed only small variability from mean values (delta $\mathrm{O}_{3}=-2$ to +2 ppbv) during the summer monsoon season. Neither our limited measurements nor the model simulations exhibit any tendency of net photochemical production of $\mathrm{O}_{3}$ after sunrise during the monsoon. The observations available during 5-14 hrs on July 23 and 24, 2009 also do not show any daytime enhancement in $\mathrm{O}_{3}$ mixing ratios. A net daytime photochemical build up in $\mathrm{O}_{3}$ has been reported over the BoB during both pre-monsoon (Nair et al. 2011) and post-monsoon season (Mallik et al. 2013), as shown for comparison in figure 5 . The absence of net $\mathrm{O}_{3}$ build-up suggests that spatio-temporal variations in surface

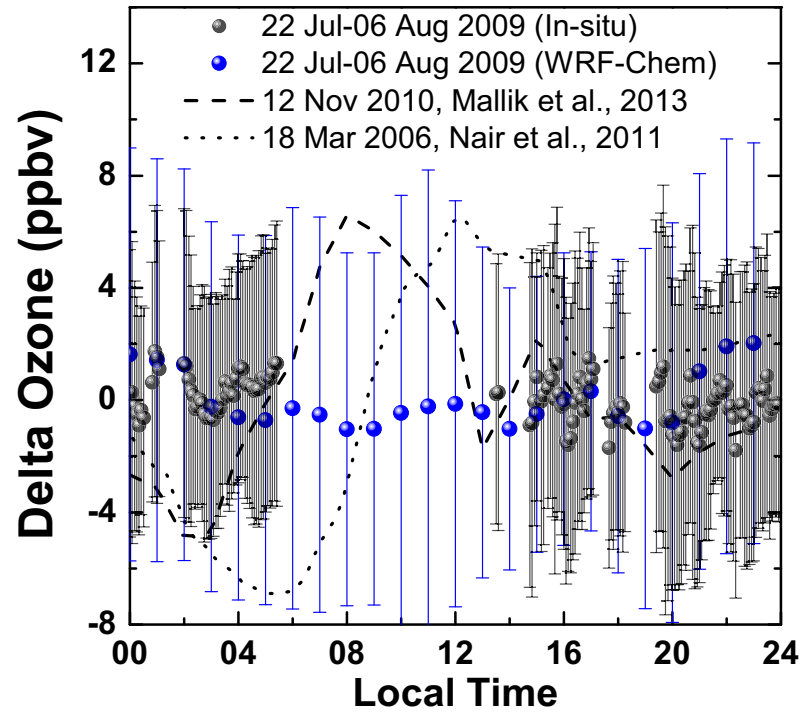

Figure 5. The mean delta-diurnal variation of surface $\mathrm{O}_{3}$ at a stationary location $\left(89^{\circ} \mathrm{E}, 19^{\circ} \mathrm{N}\right)$ over the $\mathrm{BoB}$, along with that from WRF-Chem simulations during summer monsoon. The dotted and dashed curves show the diurnal variations in surface $\mathrm{O}_{3}$ (adopted from Nair et al. 2011 and Mallik et al. 2013) during pre-monsoon and post-monsoon season, respectively.

$\mathrm{O}_{3}$ over the $\mathrm{BoB}$ during monsoon season are associated with the direct transport supplemented with en route photochemistry. Note that, due to the insufficient number of observations, diurnal variations in $\mathrm{CO}$ and $\mathrm{CH}_{4}$ could not be studied here.

The earlier observations (Lal et al. 1998; Lal and Lawrence 2001; David et al. 2011; Nair et al. 2011; Mallik et al. 2013) have shown in situ photochemical production of $\mathrm{O}_{3}$ over the AS and the BoB, especially in the coastal air masses or polluted air masses. In these studies, enhancements in the mixing ratios of $\mathrm{O}_{3}$ were observed during daytime or in the morning hours. But in the remote marine regions, $\mathrm{O}_{3}$ shows 'virtually no diurnal variation' (Liu et al. 1983) indicating absence of net in situ photochemical production. Similar to the present study, there are observations (Naja et al. 2004; Sahu et al. 2006; Lal et al. 2007; Ali et al. 2009) which show no net $\mathrm{O}_{3}$ photochemical production. Mainly scarcity of $\mathrm{O}_{3}$ precursor gases over remote marine environment limits the photochemical production of $\mathrm{O}_{3}$. In the present study, absence of in situ photochemical production of $\mathrm{O}_{3}$ could be attributed to cloudy conditions of monsoons as well as lower concentration of precursor gases. Table 1 summarises the ranges of $\mathrm{O}_{3}$ mixing ratios over different marine regions and whether in situ photochemical production was observed. Table 1 is further discussed in section 5.5. 


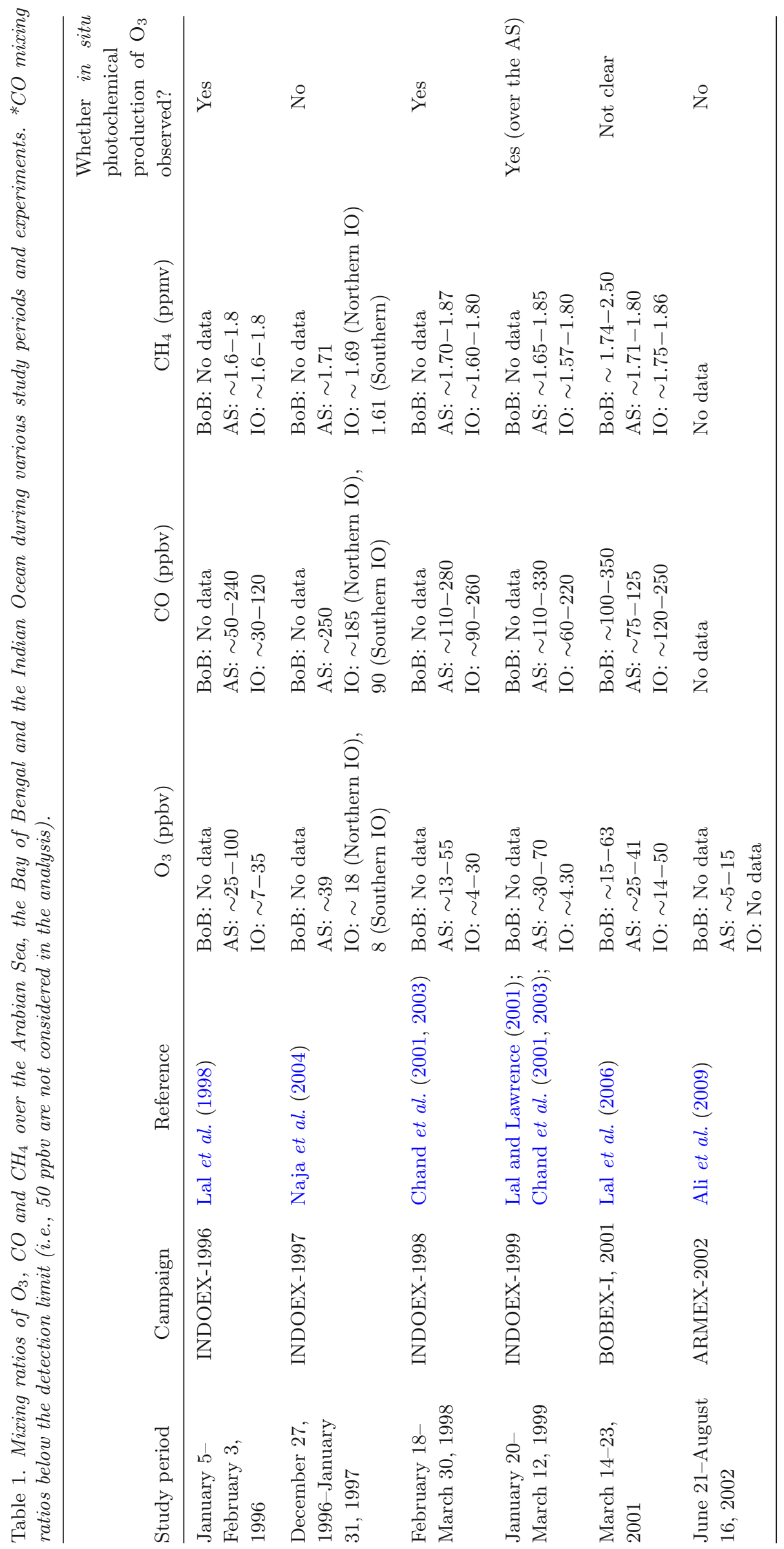




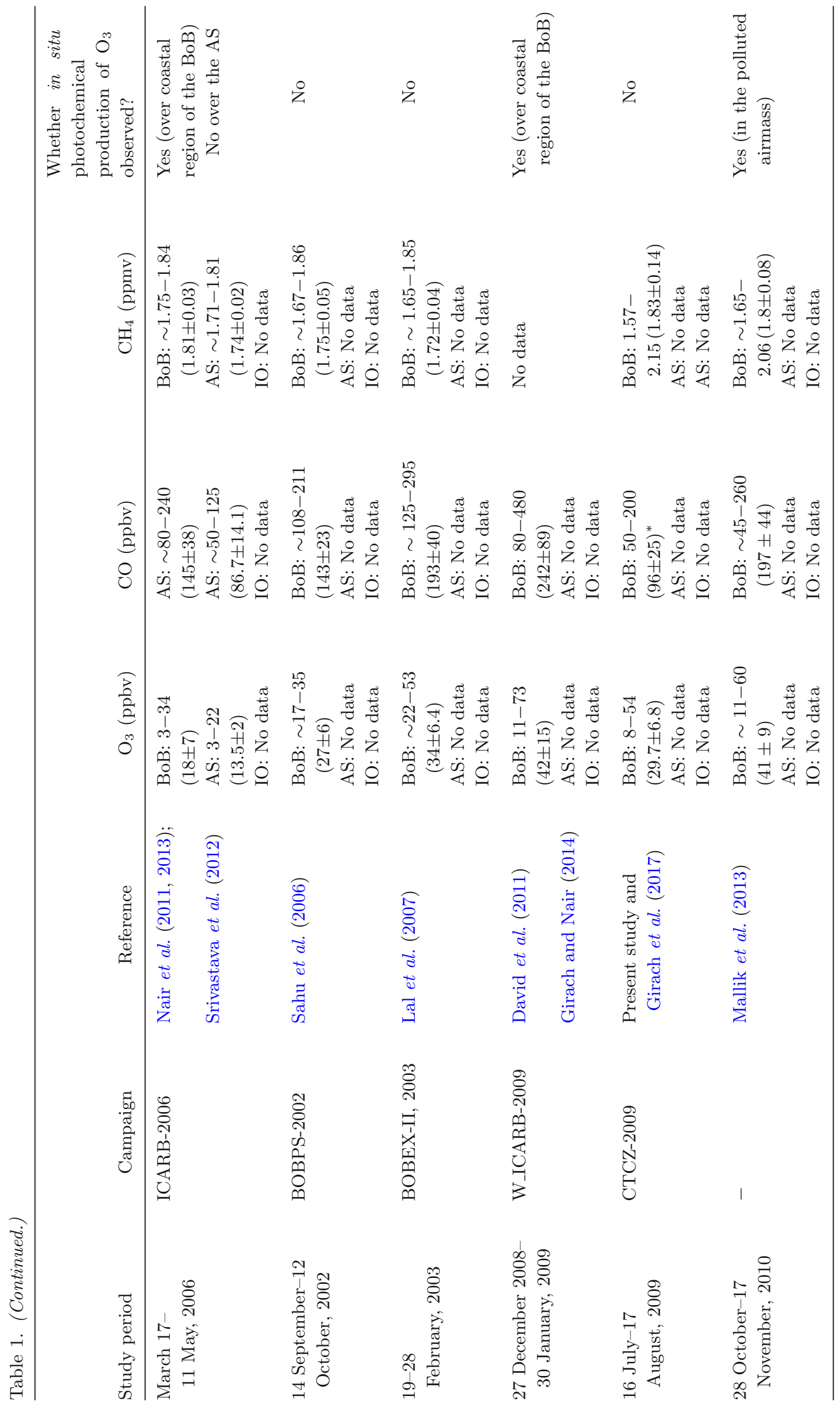




\subsection{Comparison of in situ measured $\mathrm{CH}_{4}$ with AIRS retrievals}

Figure 6 (top panel) shows the temporal variation of in situ measured $\mathrm{CH}_{4}$ along with AIRS retrievals at $925 \mathrm{hPa}$. Figure 6 (bottom panel) shows the scatter plot analysis between the two datasets. AIRS retrievals of $\mathrm{CH}_{4}$ lie around 1.8 ppmv, showing a limitation in capturing the variability as indicated by the large deviation from 1:1 line. The correlation coefficient is also low (0.17) and statistically insignificant. This might have been due to presence of thick clouds during the study period. This highlights the need for more in situ measurements of trace gases during summer monsoon over the Indian subcontinent and the adjacent marine regions. Note that, the comparisons for $\mathrm{O}_{3}$ and $\mathrm{CO}$ are not possible to carry out due to unavailability of satellite data under cloudy conditions.

\subsection{Correlation between surface $\mathrm{CH}_{4}$ and $\mathrm{O}_{3}$}

Since the surface $\mathrm{O}_{3}$ measurements are of high temporal resolution, $30 \mathrm{~min}$ of $\mathrm{O}_{3}$ measurements were averaged around the sampling time of $\mathrm{CH}_{4}$ for the correlation analysis. Figure 7 shows the scatter plot between thus calculated 30-min mean $\mathrm{O}_{3}$ and $\mathrm{CH}_{4}$. As discussed in subsection 5.2, a net photochemical production of $\mathrm{O}_{3}$ is not observed during the monsoon (present study) and hence the in situ production of $\mathrm{O}_{3}$ from methane would have contributed insignificantly to the observed variations in $\mathrm{O}_{3}$ over the $\mathrm{BoB}$. Thus, the observed strong positive correlation $(R=0.64)$ between $\mathrm{O}_{3}$ and $\mathrm{CH}_{4}$ is attributed to their transport from common source regions. In addition, there could be a contribution from methane oxidation to $\mathrm{O}_{3}$ formation over the source regions.

Similar correlation analysis was carried out for $\mathrm{CO}$ and $\mathrm{O}_{3}$ (not shown here). CO being a precursor for $\mathrm{O}_{3}$, was expected to exhibit positive correlation with $\mathrm{O}_{3}$. But no statistically significant correlation between $\mathrm{CO}$ and $\mathrm{O}_{3}$ was observed, probably due to the absence of photochemistry.

\subsection{Comparison with earlier measurements}

There are several measurements of $\mathrm{O}_{3}, \mathrm{CO}$ and $\mathrm{CH}_{4}$ over the $\mathrm{AS}$, the BoB and the $\mathrm{IO}$ during various seasons. The ranges of concentration levels are shown in table 1 . As discussed in section 5.2, table 1 also includes whether photochemical production of $\mathrm{O}_{3}$ was observed during various studies. In the
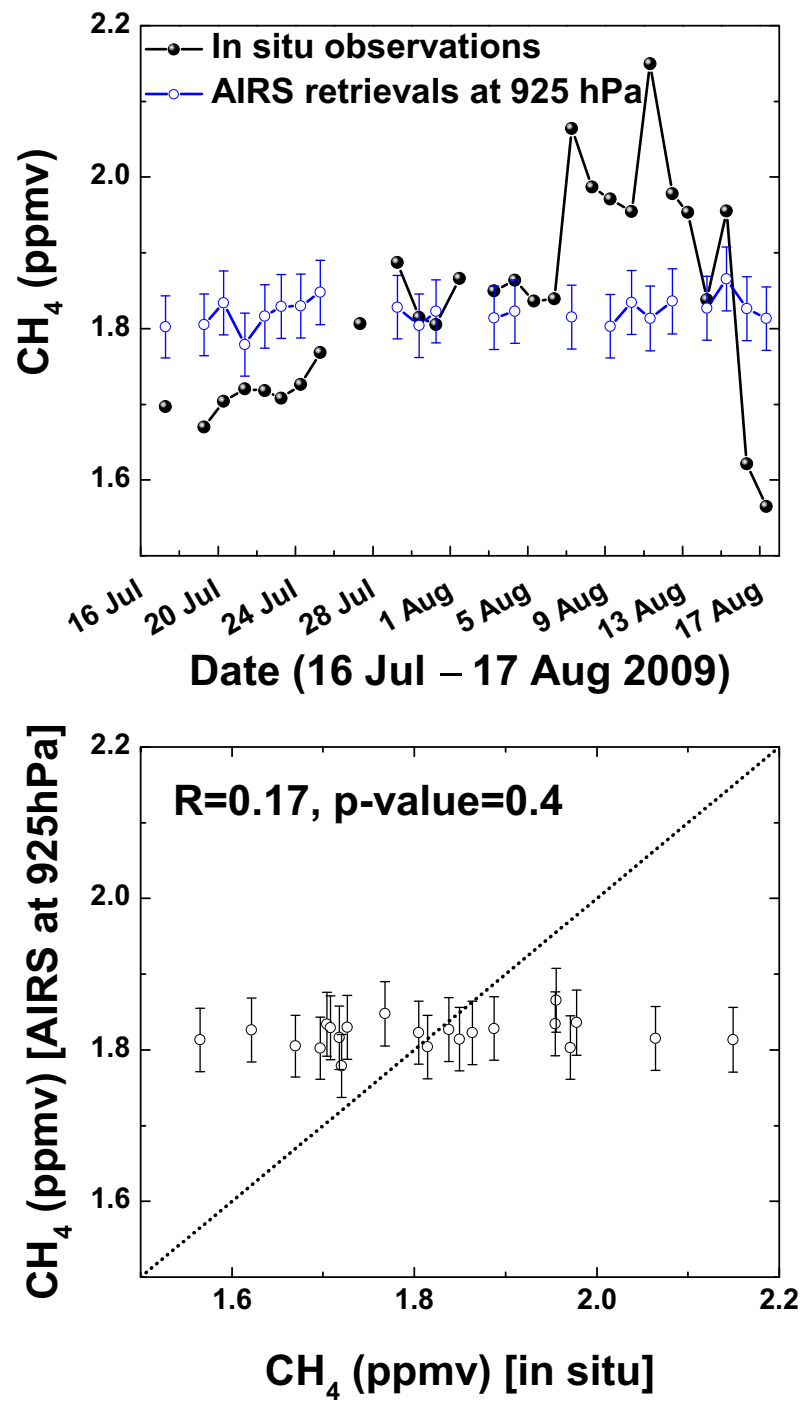

Figure 6. Temporal variation of in situ measured $\mathrm{CH}_{4}$ along with those retrieved from AIRS at $925 \mathrm{hPa}$ along the cruise track over the BoB (top panel) during summer monsoon. Scatter plot analysis between the in situ measurements and AIRS retrievals of $\mathrm{CH}_{4}$ at $925 \mathrm{hPa}$ (bottom panel). Error bars show the error in the retrieved $\mathrm{CH}_{4}$. The dotted line is the 1:1 line. The AIRS retrieved $\mathrm{CH}_{4}$ mixing ratios were obtained from the AIRS website.

present study surface $\mathrm{O}_{3}, \mathrm{CO}$ and $\mathrm{CH}_{4}$ varied from 8 to $54 \mathrm{ppbv}, 50$ to $200 \mathrm{ppbv}$ and 1.57 to $2.15 \mathrm{ppmv}$, respectively. The earlier study shows surface $\mathrm{O}_{3}$ as low as $~ 5$ ppbv (June-August 2002; Ali et al. 2009) and as high as 100 ppbv (January-February, 1996; Lal et al. 1998) over the AS. CO was observed to be as low as 30 ppbv (January-February, 1996; Lal et al. 1998) over the IO and as high as $480 \mathrm{ppbv}$ (December 2008-January 2009; Girach and Nair $2014)$ over the $\mathrm{BoB}$. The lower value of $\mathrm{CH}_{4}(\sim 1.57$ ppmv) was observed over the IO (January-March, 1999; Chand et al. 2001) which is similar to what is observed in the present study. The higher mixing 


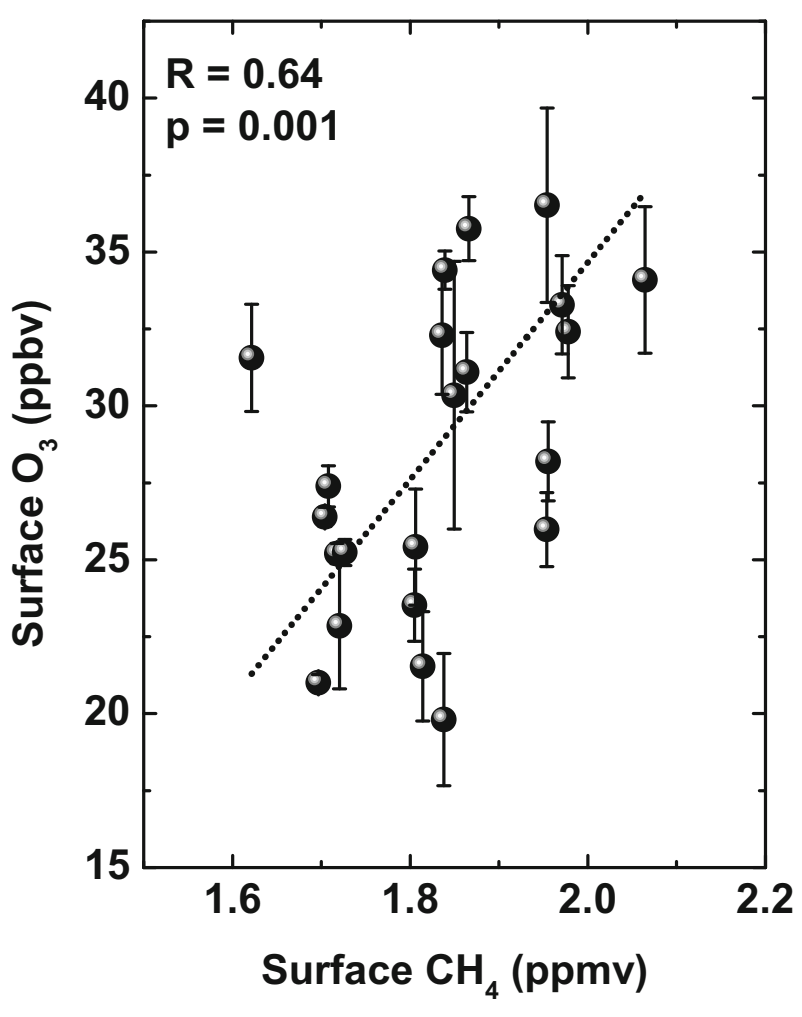

Figure 7. Scatter plot between in situ measured surface $\mathrm{O}_{3}$ and $\mathrm{CH}_{4}$ mixing ratios during 16 July-17 August, 2009 over the BoB. The Y-error bar represents the standard deviation in 30-min of continuous $\mathrm{O}_{3}$ measurements around the sampling time of methane. A linear regression fit is shown by the dotted line.

ratio of $\mathrm{CH}_{4}$ was observed to be 2.5 ppmv over the BoB (March 2001; Lal et al. 2006).

\section{Summary}

In this paper, we presented the ship-borne measurements of trace gases $\left(\mathrm{O}_{3}, \mathrm{CO}\right.$, and $\left.\mathrm{CH}_{4}\right)$ which were carried out as a part of the CTCZ experiment over the BoB during July-August 2009, for the first time during the summer monsoon. A comparison of these measurements with satellite data (AIRS) and model simulations (MACC reanalysis and WRF-Chem) is also made. The main conclusions from the study are as follows:

- The averaged tropospheric $\mathrm{O}_{3}$ is slightly higher over coastal and northern BoB (35-40 ppbv) as compared to central and southern BoB (30-35 ppbv). This feature is similar to that of surface $\mathrm{O}_{3}$.

- The observed mixing ratios of surface $\mathrm{O}_{3}, \mathrm{CO}$, and $\mathrm{CH}_{4}$ during the summer monsoon period are generally reproduced by a global reanalysis, MACC. The MACC, typically overestimated absolute levels of $\mathrm{O}_{3}$ and $\mathrm{CH}_{4}$ by $1.6 \mathrm{ppbv}$ and $0.07 \mathrm{ppmv}$, respectively and underestimated CO by 2.6 ppbv. These small biases show the capabilities of MACC reanalysis in reproducing observed levels of $\mathrm{O}_{3}, \mathrm{CO}$, and $\mathrm{CH}_{4}$ over the $\mathrm{BoB}$ during summer monsoon season.

- The mean diurnal variations in $\mathrm{O}_{3}$ at a stationary location over the $\mathrm{BoB}$ did not show a net photochemical buildup during monsoon, indicating that the observed $\mathrm{O}_{3}$ variations were primarily due to transport supplemented with en-route photochemistry.

- In situ measurement of $\mathrm{CH}_{4}$ shows only small correlation coefficient with satellite retrievals during the CTCZ experiment, which highlights the need for more in situ observations during the monsoon season over the Indian subcontinent.

- $\mathrm{O}_{3}$ mixing ratios show strong positive correlation of 0.64 with surface $\mathrm{CH}_{4}$ indicating the transport of $\mathrm{O}_{3}$ (and precursors) from common source regions to the $\mathrm{BoB}$.

\section{Acknowledgements}

We thank CTCZ and ICRP organizers for providing the opportunity to participate in the CTCZ experiment. We are thankful to the Director, National Centre for Antarctic and Ocean Research (NCAOR), Goa for providing shipboard facilities. The AIRS $\mathrm{CH}_{4}$ mixing ratios were obtained from website http://mirador.gsfc.nasa.gov/. The MACC reanalysis data were obtained from http://apps. ecmwf.int/datasets/data/macc-reanalysis/ and we greatly acknowledge MACC Reanalysis project. The Dutch-Finnish-built OMI is part of the NASA EOS Aura satellite payload. The OMI project is managed by NIVR and KNMI in the Netherlands. The tropospheric ozone data were obtained from https://acd-ext.gsfc.nasa.gov/Data_services/ cloud_slice/. The comments and suggestions from two anonymous reviewers are gratefully acknowledged.

\section{References}

Ali K, Beig G, Chate D M, Momin G A, Sahu S K and Safai, P D 2009 Sink mechanism for significantly low level of ozone over the Arabian Sea during monsoon; J. Geophys. Res. 114 D17306, https://doi.org/10.1029/ 2008JD011256.

Chand D, Modh K S, Naja M, Venkataramani S and Lal S 2001 Latitudinal trends in $\mathrm{O}_{3}, \mathrm{CO}, \mathrm{CH}_{4}$, and $\mathrm{SF}_{6}$ over the Indian Ocean during the INDOEX IFP-1999 ship cruise; Curr. Sci. 80 100-104. 
Chand D, Lal S and Naja M 2003 Variations of ozone in the marine boundary layer over the Arabian Sea and the Indian Ocean during the 1998 and 1999 INDOEX campaigns; J. Geophys. Res. 108(D6) 4190, https://doi.org/ 10.1029/2001JD001589.

David L M, Girach I A and Nair P R 2011 Distribution of ozone and its precursors over Bay of Bengal during winter 2009: Role of meteorology; Ann. Geophys. 29 1613-1627, https://doi.org/10.5194/angeo-29-1613-2011.

Girach I A and Nair P R 2014 On the vertical distribution of carbon monoxide over Bay of Bengal during winter: Role of water vapour and vertical updrafts; J. Atmos.SolarTerrestrial Phys. 117 31-47, https://doi.org/10.1016/j. jastp.2014.05.003.

Girach I A, Ojha N, Nair P R, Pozzer A, Tiwari Y K, RaviKumar $\mathrm{K}$ and Lelieveld $\mathrm{J} 2017$ Variations in $\mathrm{O}_{3}$, $\mathrm{CO}$, and $\mathrm{CH}_{4}$ over the Bay of Bengal during the summer monsoon season: Shipborne measurements and model simulations; Atmos. Chem. Phys. 17 257-275, https://doi. org/10.5194/acp-17-257-2017.

Inness A, Baier F, Benedetti A, Bouarar I, Chabrillat S, Clark H, Clerbaux C, Coheur P, Engelen R J, Errera Q, Flemming J, George M, Granier C, Hadji-Lazaro J, Huijnen V, Hurtmans D, Jones L, Kaiser J W, Kapsomenakis J, Lefever K, Leitão J, Razinger M, Richter A, Schultz M G, Simmons A J, Suttie M, Stein O, Thépaut J-N, Thouret V, Vrekoussis M, Zerefos C and the MACC team 2013 The MACC reanalysis: An 8 yr data set of atmospheric composition; Atmos. Chem. Phys. 13 4073-4109, https://doi.org/10.5194/acp-13-4073-2013.

IPCC-AR5 2013 Fifth Assessment Report of the Intergovernmental Panel on Climate Change.

Katragkou E, Zanis P, Tsikerdekis A, Kapsomenakis J, Melas D, Eskes H, Flemming J, Huijnen V, Inness A, Schultz M G, Stein O and Zerefos C S 2015 Evaluation of near surface ozone over Europe from the MACC reanalysis; Geosci. Model Dev. Discuss. 8 1077-1115, https://doi. org/10.5194/gmdd-8-1077-2015.

Lal S, Naja M and Jayaraman A 1998 Ozone in the marine boundary layer over the tropical Indian Ocean; J. Geophys. Res. 103(D15) 18907-18917, https://doi.org/10. 1029/98JD01566.

Lal S and Lawrence M G 2001 Elevated mixing ratios of surface ozone over the Arabian Sea; Geophys. Res. Lett. 28 1487-1490.

Lal S, Chand D, Sahu L K, Venkataramani S, Brasseur G and Schultz M G 2006 High levels of ozone and related gases over the Bay of Bengal during winter and early spring of 2001; Atmos. Environ. 40 1633-1644.

Lal S, Sahu L K and Venkataramani S 2007 Impact of transport from the surrounding continental regions on the distributions of ozone and related trace gases over the Bay of Bengal during February 2003; J. Geophys. Res. 112 D14302, https://doi.org/10.1029/2006JD008023.

Lawrence M G and Lelieveld J 2010 Atmospheric pollutant outflow from southern Asia: a review; Atmos. Chem. Phys. 10 11017-11096, https://doi.org/10.5194/ acp-10-11017-2010.
Liu S C, McFarland M, Kley D, Zafiriou O and Huebert B 1983 Tropospheric $\mathrm{NOx}$ and $\mathrm{O}_{3}$ budgets in the equatorial Pacific; J. Geophys. Res. 88 1360-1368.

Mallik C, Lal S, Venkataramani S, Naja M and Ojha N 2013 Variability in ozone and its precursors over the Bay of Bengal during post monsoon: Transport and emission effects; J. Geophys. Res. Atmos. 118, https://doi.org/10. $1002 /$ jgrd.50764.

Naja M, Chand D. Sahu L and Lal S 2004 Trace gases over marine regions around India; Ind. J. Mar. Sci. 33(1) 95-106.

Nair P R, David L M, Girach I A and George S K 2011 Ozone in the marine boundary layer of Bay of Bengal during post-winter period: Spatial pattern and role of meteorology; Atmos. Environ. 45 4671-4681, https://doi.org/10. 1016/j.atmosenv.2011.05.040.

Nair P R, David L M, Aryasree S and George S K 2013 Distribution of ozone in the marine boundary layer of Arabian Sea prior to monsoon: Prevailing airmass and effect of aerosols; Atmos. Environ. 74 18-28, https://doi.org/10. 1016/j.atmosenv.2013.02.049.

Ojha N, Pozzer A, Rauthe-Schöch A, Baker A K, Yoon J, Brenninkmeijer C A M and Lelieveld J 2016 Ozone and carbon monoxide over India during the summer monsoon: regional emissions and transport; Atmos. Chem. Phys. 16 3013-3032, https://doi.org/10.5194/acp-16-3013-2016.

Ravikumar K, Tiwari Y K, Valsala V and Murtugudde R 2014 On understanding of land-ocean $\mathrm{CO}_{2}$ contrast over Bay of Bengal: A case study during 2009 summer monsoon; Environ. Sci. Poll. Res. 21-7 5066-5075, https:// doi.org/10.1007/s11356-013-2386-2.

Sahu L K, Lal S and Venkataramani S 2006 Distributions of $\mathrm{O}_{3}$, CO and hydrocarbons over the Bay of Bengal: A study to assess the role of transport from southern India and marine regions during September-October 2002 Atmos. Atmos. Environ. 40 4633-4645, https://doi.org/10.1016/ j.atmosenv.2006.02.037.

Seinfeld J H and Pandis S N 2006 Atmospheric Chemistry and Physics: from air pollution to climate change, 2nd edn, Wiley-Interscience publication, USA.

Srivastava S, Lal S, Venkataramani S, Gupta S and Sheel V 2012 Surface distributions of $\mathrm{O}_{3}, \mathrm{CO}$ and hydrocarbons over the Bay of Bengal and the Arabian Sea during premonsoon season; Atmos. Environ. 47 459-467, https:// doi.org/10.1016/j.atmosenv.2011.10.02.

Sharma A, Ojha N, Pozzer A, Mar K A, Beig G, Lelieveld J and Gunthe S S 2016 WRF-Chem simulated surface ozone over South Asia during the pre-monsoon: Effects of emission inventories and chemical mechanisms; Atmos. Chem. Phys. Discuss., https://doi.org/10.5194/acp-2016-1083.

Ziemke J R, Chandra S, Duncan B N, Froidevaux L, Bhartia P K, Levelt P F and Waters J W 2006 Tropospheric ozone determined from AURA OMI and MLS: Evaluation of measurements and comparison with the Global Modeling Initiative's Chemical Transport Model; J. Geophys. Res. 111 D19303, https://doi.org/10.1029/ 2006JD007089. 